\title{
The Effect of Posture on Ventilatory Muscle Function and Lung Function
}

\author{
P. GOUNDEN
}

\section{SUMMARY}

The purpose of this study was to determine the influence of posture on ventilatory muscle strength and on lung function.

Maximum static inspiratory pressures (MIPS), maximum static expiratory pressures (MEPS) and lung function measurements (FVC, FEV PEFR) were obtained in three different body positions in 57 normal subjects and in 16 asthmatic patients.

Statistical analysis of the data obtained showed that changes in position influence the ventilatory muscle function and lung function values.

The sitting lean forward and the sitting erect positions were the better positions in the normal group. The findings revealed that the sitting lean forward position was the optimum position for the asthmatic group $(p<0,001)$.
Alterations in lung function as affected by changes in posture have been investigated previously. ${ }^{1,2,3,4,5}$ Oniell and associates ${ }^{6}$ found in their study that the seated leaning forward position yielded optimum results in a group of patients with chronic airflow limitation in terms of inspiratory muscle performance and relief of dyspnoea.

Routine chest care by physiotherapists often necessitates alterations in position in order to obtain optimum effects. Only a few studies have been undertaken by physiotherapists to ascertain the effects of posture on lung function. Crosbie ${ }^{7}$ and $\mathrm{Hough}^{8}$ have shown that the slumped posture caused a reduction in lung function in hospital patients.

The present study was undertaken to examine the effect of three postures, sitting erect (SE), sitting lean forward (SLF) and supine lying (SL) on ventilatory muscle performance and on lung function.

The main aims of the study were:

(i) to investigate the effect of posture on ventilatory

P. Gounden, M.Physiotherapy Senior Lecturer, University of Durban-Westville and King Edward VIll Hospital

\section{OPSOMMING}

Die doel van hierdie studie was om die invloed van postuur op ventilatoriese-spiersterkte en op longfunksie vas te stel.

Maksimale statiese inspiratoriese druk (MIPS), maksimale statiese ekspiratoriese druk (MEPS) en longfunksie mate (FVC, FEV $p_{1}$ PEFR) was in drie verskillende lyfposisies verkry in 57 normale persone en in 16 asmatiese pasiënte.

Statistiese ontleding van die data het getoon dat veranderinge in lyfposisie die ventilatoriese-spierfunksie en longfunksie beïnvloed.

Die sit-vooroorleun en die sit-regop posisies was die beste posisies in die normale groep. Die bevindinge het bewys dat die sit-vooroorleun posisie die optimale posisie was vir die asmatiese groep $(p<0,001)$.

muscle performance as expressed by maximum static respiratory pressures in a group of normal individuals and in a group of chronic asthmatics.

(ii) To examine the effect of posture on forced vital capacity (FVC), forced expiratory volume in one second $\left(\mathrm{FEV}_{1}\right)$ and on peak expiratory flow rate (PEFR) in the same study groups.

(iii) to determine the degree to which changes in position effected lung function and ventilatory muscle strength in each group.

\section{METHOD}

The first study group consisted of 57 university students (48 female and 9 male) with ages ranging from $17-23$ years. The second study group consisted of 16 chronic asthmatics ( 9 male and 7 female) with ages ranging from 30-55 years. The asthmatic group was studied either in remission or just after an acute attack. All patients in this group were receiving daily bronchodilator therapy.

Maximum static inspiratory (MIPS) and expiratory (MEPS) pressures were used as indices of ventilatory muscle strength. The MIPS and MEPS manometer was used to measure the above pressures. This manometer is similar in function to the instruments used by 
Table 1. Normal Group - Maximum values

$\begin{array}{cccccc}\text { Position } & \text { FVC litres } & \text { FEV litres } & \text { PEFR L/M } & \text { MEPS cm/H20 } & M I P S \mathrm{~cm} / H 20 \\ \text { SLF } & 2,8 \pm, 74 & 2,7 \pm, 69 & 377,9 \pm 96,8 & 75,2 \pm 13,6 & -77,1 \pm 15,2 \\ \text { SE } & 2,8 \pm, 78 & 2,7 \pm, 70 & 378,9 \pm 89,3 & 73,2 \pm 14 & -72,9 \pm 19,4 \\ \text { SL } & 2,6 \pm, 71 & 2,5 \pm, 66 & 349,9 \pm 89,4 & 70,2 \pm 15,2 & -72,6 \pm 17,3\end{array}$

Mean \pm ISD

$2,8 \pm, 78$

$349,9 \pm 89,4$

Table 2. Asthmatic Group - Maximum values

$\begin{array}{cc}\text { Position } & \text { FVC litres } \\ \text { SLF } & 1,6 \pm, 64 \\ \text { SE } & 1,3 \pm, 63 \\ \text { SL } & 1,2 \pm, 56\end{array}$

$$
\begin{aligned}
& F E V_{1} \text { litres } \\
& 1,2 \pm, 55 \\
& 1,1 \pm, 59 \\
& 1,0 \pm, 53
\end{aligned}
$$

PEFR $L / M$
$174,4 \pm 98,7$
$162,6 \pm 85,3$
$136,1 \pm 84,5$
MEPS $\mathrm{cm} / \mathrm{H} 20$
$79,3 \pm 22,1$
$75,1 \pm 20,4$
$69,9 \pm 25,2$
MIPS $\mathrm{cm} / \mathrm{H} 20$
$-66,4 \pm 22,1$
$-61,3 \pm 23,9$
$-56,8 \pm 23,1$

investigators abroad. It is a reliable method of assessing ventilatory muscle strength. ${ }^{9,10,11,12}$

Maximum static inspiratory and expiratory pressures were measured in three starting positions viz. sitting erect, sitting lean forward (sitting flexed forward to $45^{\circ}$ ), and in supine lying. The measurements were recorded in centimetres of water. All subjects were instructed to press their lips tightly around the mouth piece during pressure measurements to prevent airleaks.

The MIPS were measured at residual volume and MEPS at total lung capacity. Repeated determinations were made until 2 technically satisfactory measurements were obtained. The highest value obtained was recorded. In a few asthmatic patients repeated determinations were not possible. In such cases the first value was recorded.

There was a short rest period after measurements were effected in each position. The order of the positions in which the pressures were measured was varied in random sequence.

After a short rest, spirometric measurements were obtained in the identical study positions using a hand held pocket spirometer.* This turbine spirometer has been found to be as accurate as any other spirometer in use. ${ }^{13}$ One of the reasons for choosing this spirometer was its ability to measure three indices (FVC, FEV and PEFR) in a single expiratory effort. The order of the positions in which the spirometric measurements was obtained was again varied in random sequence.

\section{RESULTS}

Five tests were conducted on each subject in both groups. Each starting position provided five measurements. Fifteen values were therefore obtained from each subject. The values were then compiled into five sets of data to calculate the mean for each test in all study positions. Tables I and II present the mean values and standard deviation for the five tests in each study position.

The best position for each test was determined by comparing their mean values in the different staring

*Designed by Micro Medical Instruments positions. The method of comparison in both the normal as well as in the asthmatic group was as follows:

Mean value of TEST 1 in SE vs Mean value of TEST 1 in SLF

Mean value of TEST 1 in SE vs Mean value of TEST 1 in SL

Mean value of TEST 1 in SLF vs Mean value of TEST 1 in $\mathrm{SL}$

This was an internal comparison within each group.

The five tests were compared in this manner. The student's $t$-test was used to analyse the results. Significant differences between mean values in different study position are presented in the following tables. The results are presented in the order of tests performed. Only results with significant differences are presented.

\section{Forced Vital Capacity}

Table III presents the values for FVC in SLF and in SL positions in the normal group.

Table 3. Comparison of FVC values between SLF and SL in the normal group

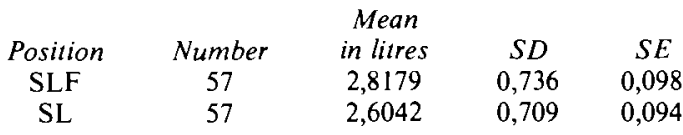

$$
\text { DF } 56 \quad \mathrm{p}<0,001
$$

There was a significant difference in the above two positions. Similar results $(p<0,001)$ were obtained when SE was compared with SL.

Therefore SLF and SE were superior to SL with reference to FVC in the normal group.

Unlike the normal group the FVC values for the asthmatic group showed that the SLF position was superior to both the SE and SL positions.

\section{Forced Expiratory Volume}

Comparison of the mean values for $\mathrm{FEV}_{1}$ in different study positions revealed same results as for FVC.

The SLF and SE positions were superior to SL in the normal group $(P<0,001)$. 
Table 4. Comparison of FVC values for SLF and SL in the asthmatic group

$\begin{array}{ccccc}\text { Position } & \text { Number } & \begin{array}{c}\text { Mean } \\ \text { in litres }\end{array} & S D & S E \\ \text { SLF } & 16 & 1,5800 & 0,637 & 0,159 \\ \text { SL } & 16 & 1,2312 & 0,563 & 0,141 \\ & & & & \\ & & \text { DF } & 15 & \end{array}$

Table 5. Comparison of $\mathrm{FEV}_{1}$ values for SE and SL in normal group

$\begin{array}{ccccc}\text { Position } & \text { Number } & \begin{array}{c}\text { Mean } \\ \text { (litres) }\end{array} & S D & S E \\ \text { SE } & 57 & 2,6853 & 0,697 & 0,092 \\ \text { SL } & 57 & 2,4805 & 0,658 & 0,087 \\ & & & & \\ & & \text { DF } & 56 & \end{array}$

Comparison of mean FEV, values in the asthmatic group showed that there was only one superior position, i.e. SLF.

Table 6. Comparison of FEV, values for SLF and SL in the asthmatic group

$\begin{array}{ccccc}\text { Position } & \text { Number } & \begin{array}{c}\text { Mean } \\ \text { (litres) }\end{array} & S D & S E \\ \text { SLF } & 16 & 1,2125 & 0,554 & 0,138 \\ \text { SL } & 16 & 1,0044 & 0,525 & 0,131 \\ & & & & \\ & & \text { DF } 15 & & \end{array}$

\section{Peak Expiratory Flow Rate}

The two sitting positions in the normal group (SE, SLF) proved to be equally effective with reference to optimum PEFR values.

However, comparison between the sitting and lying positions yielded a significant difference.

Table 7. Comparison of PEFR values in SE and SL positions in the normal group

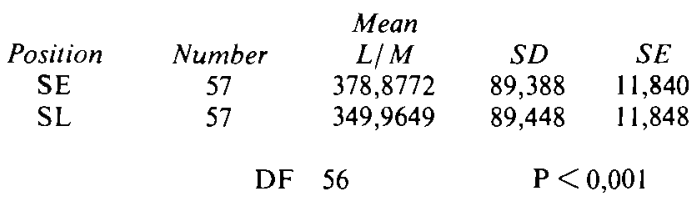

Comparison of PEFR values in the asthmatic group showed that the SLF position was superior to the other 2 positions.

Table 8. Comparison of PEFR value between SLF and SL in the asthmatic group

$\begin{array}{ccccc}\text { Position } & \text { Number } & \text { Mean } & \\ \text { SLF } & 16 & 174,4375 & S D & S E \\ \text { SL } & 16 & 136,1250 & 84,720 & 24,680 \\ & & & & 21,122 \\ & & \text { DF } & 15 & \mathrm{p}<0,001\end{array}$

Ventilatory muscle strength as represented by static respiratory pressures

a) Maximal Static Expiratory Pressure (MEPS)

Comparison of mean values for MEPS in the 3 positions in the normal group showed that the SLF position was superior to the other two positions. Expiratory muscle function was therefore optimum in the SLF position.

Table 9. Comparison of mean values for MEPS between SLF and $\mathrm{SL}$ in the normal group

$\begin{array}{ccccc}\text { Position } & \text { Number } & \text { Mean } & \\ \text { SLF } & 57 & 75,1930 & S D & S E \\ \text { SL } & 57 & 70,2456 & 13,586 & 1,800 \\ & & & & \\ & & \text { DF } & 56 & \end{array}$

Comparison of values for MEPS in the other positions failed to show significant difference in the normal group although there was some difference between SE and SL $(p<0,05)$.

The mean values for MEPS in the asthmatic group revealed that the SLF position was the best position. Expiratory pressure generated in the SLF position was higher than pressures generated in SE and in SL.

Table 10. Comparison of mean MEPS values for SLF and SL in the asthmatic group

\begin{tabular}{ccccc}
\multicolumn{5}{c}{ Mean } \\
Position & Number & $c m / H 20$ & $S D$ & $S E$ \\
SLF & 16 & 79,3125 & 22,057 & 5,514 \\
SL & 16 & 69,8750 & 25,211 & 6,303 \\
& & & & \\
& & & &
\end{tabular}

b) Maximum Static Inspiratory Pressures (MIPS)

Comparison of mean values for MIPS showed clearly that the SLF position was the position of choice in the normal and in the asthmatic group. The SE and SL positions generated lower inspiratory pressures than the SLF position.

Table 11. Comparison of mean values for MIPS in SLF and $S L$ in the normal group

\begin{tabular}{|c|c|c|c|c|}
\hline Position & Number & $\begin{array}{c}\text { Mean } \\
\mathrm{cm} / \mathrm{H} 20\end{array}$ & $S D$ & $S E$ \\
\hline SLF & 57 & $-77,0702$ & 15,169 & 2,009 \\
\hline $\mathrm{SL}$ & 57 & $-72,5789$ & 17,258 & 2,286 \\
\hline & D & 56 & \multicolumn{2}{|c|}{$P<0,001$} \\
\hline
\end{tabular}

Comparison of mean values for MIPS in the above positions yielded similar results in the asthmatic group.

\section{DISCUSSION}

Statistical analysis from the data obtained in this study shows small, but significant differences in the 
ventilatory muscle function values and lung function values as a result of changes in position.

The position of supine lying reduces both lung function as well as ventilatory muscle function values in the respiratory compromised and the normal subject. Sitting erect or sitting leaning forward at $45^{\circ}$ are equally good postures in normal subjects. In all the comparisons, the sitting leaning forward position for the patient with chronic obstructive lung disease was the optimum posture for function. This confirms previous reports ${ }^{2,5}$ that these patients obtain relief from dyspnoea by sitting in this position.

The positions selected for this study are of significance to the clinical physiotherapist. Lung function tests and more latterly ventilatory muscle function testing are frequently carried out by the clinical physiotherapist. Since the starting positions cause variations in values, they need to be standardised in order to obtain reliable measurements.

It can be seen from tables I and II that the measurements of ventilatory muscle strength are slightly more sensitive to position changes than lung function values. This is even more marked in the respiratory compromised group. The forward sitting position generated the highest maximum inspiratory and expiratory pressures in both groups. One can deduce from this that the optimum position for training breathing control in patients with chronic airflow limitation, is the forward lean position.

The measurement of ventilatory muscle strength in patients suffering from Guillain Barré Syndrome as well as tetraplegic patients is becoming mandatory in some centres. The fact that MIPS and MEPS measurements are changed by the position of the patients must be taken into account. In the acute phase both Guillain Barré patients and tetraplegics are nursed in supine. Thus the values obtained do not necessarily reflect accurately the actual ventilatory muscle strength.

\section{CONCLUSION}

It appears from this study that changes in posture affect ventilatory muscle strength values more than lung function values. The measurement of static respiratory pressures seems to be a sensitive measure of ventilatory muscle strength and of value in the assessment of the patient with chronic obstructive disease. When assessing these patients the position of the patient should be precisely controlled in order to obtain accurate values.

\section{References}

1. Williams PL and Warwick R eds. Gray's Anatomy. 36th edition. Philadelphia: W.B. Saunders, 1980.

2. Sharp JT, Druz WS, Moisan T et al. Postural relief of dyspnoea in severe chronic obstructive pulmonary disease. Am Rev Respir Dis 1980; 122: 201-211.

3. Jonsson E \& Mossberg B. Impairment of ventilatory function by supine posture in asthma. Eur $J$ Respir Dis 1984; 65: 496-503.

4. Moreno F \& Lyons $\mathbf{H}$. Effect of body posture on lung volumes. J Appl Physiol 1961; 16: 27-29.

5. Barach AL. Chronic obstructive lung disease: postural relief of dyspnoea. Arch Phys Med Rehab 1974; 55:1 494-504.

6. O'Neill S \& McCarthy DS. Postural relief of dyspnoea in severe chronic airflow limitation: relationship to respiratory muscle strength. Thorax 1983; 38: 595-600.

7. Crosbie WJ \& Myles S. An investigation into the effect of postural modification on some aspects of normal pulmonary function. Physiotherapy 1985; 71(7): 311-314.

8. Hough A. The effect of posture on lung function. Physiotherapy 1984; 70(3): 101-104.

9. Rahn H, Otis AB, Chadwick LE \& Tenn VO. The pressure volume diagram of the thorax and lungs. $A m J$ Physiol 1946; 146: 161.

10. Cook CD \& Mead J. Static volume pressure characteristics of the respiratory system during maximal efforts. $J$ Appl Physiol 1964; 19: 1016.

11. Black LF \& Hyatt RE. Maximal respiratory pressures: normal values and relationships to age and sex. $A m R e v$ Respir Dis 1969; 99: 696-702.

12. Rochester DF, Braun NMT \& Arora NS. Respiratory muscle strength in COPD. Am Rev Respir Dis 1979; 119(2): 151-154.

13. Chowienczk PJ \& Lawson CP. Pocket sized device for measuring forced expired volume in one second and forced vital capacity. $\mathrm{Br}$ Med J 1982; 285: 15-17. 